\title{
Pendampingan Pembentukan PKBM (Pusat Kegiatan Belajar Masyarakat) di Desa Mandiangin Kecamatan Rawas Ilir Kabupaten Musi Rawas Utara
}

\author{
Inda Puspita sari ${ }^{1}$, Agung Nugroho ${ }^{2}$, Septa Mila Sari ${ }^{3}$, \\ Kiki Maryani ${ }^{4}$ Enggi Wahyuni Fitri ${ }^{5}$ \\ 1,2,3,4,5 Pendidikan Bahasa dan Sastra Indonesia, STKIP-PGRI Lubuklinggau \\ Jl. Mayor Toha, Air Kuti, Kota Lubuklinggau, Sumatera Selatan 31625
}

\begin{abstract}
Abstrak
Tujuan pengabdian kepada masyarakat ini adalah pendampingan pembentukan PKBM (Pusat Kegiatan Belajar Masyarakat) di desa Mandi Angin Kec. Rawas Ilir Kabupaten Musi Rawas Utara. Metode yang digunakan adalah metode sosialisasi, pelatihan dan praktik. PKM ini adalah kegiatan pendampingan yang mengarahkan pada pembentukan struktur PKBM (Pusat Kegiatan Belajar Masyarakat). Hal ini menjadi perhatian tim PKBM karena di desa Mandi Angin belum terbentuk pusat belajar untuk masyarakat. Kegiatan pendampingan PKBM (Pusat Kegiatan Belajar Masyarakat) akan meningkatkan SDM yang mengarah pada produktifitas SDM di desa Mandi Angin. Hasil dari kegiatan PKBM (Pengabdian pada Masyarakat) di desa Mandi Angin Kecamatan Rawas Ilir kabupaten Musi Rawas Utara, diantaranya: 1) Terlaksananya koordinasi tim PKBM STKIP PGRI Lubuklinggau dengan pemerintah desa, sehingga kegiatan berlangsung aman dan lancar, 2) Terlaksananya sosialisasi pembentukan struktur PKBM (Pusat Kegiatan Belajar Masyarakat) dan direspon dengan baik oleh masyarakat, 3) Perangkat dan masyarakat desa Mandi Angin antusias mendukung pembentukan PKBM di desa, 4) Kendala yang dihadapi berkaitan dengan sulitnya mendapat masyarakat yang memiliki kompetensi yang tinggi, sebagai bagian dari struktur PKBM, dan 5) Pemerintah desa dan Masyarakat meminta kegiatan PKBM terlaksana dengan baik, tidak hanya sebatas pembentukan struktur kegiatanya saja. Secara umum hasil PKBM ini adalah terbentuknya struktur PKBM yang akan dilanjutkan pada tingkatan pelaksanaan PKBM-nya.
\end{abstract}

Kata Kunci: Pendampingan, PKBM.

\section{Pendahuluan}

Desa Mandi Angin adalah salah satu desa di kecamatan Rawas Ilir kabupaten Musi Rawas Utara. Tingkat pendidikan di desa Mandi Angin ini sangat rendah, dan masyarakatnya hanya menempuh pendidikan hingga jenjang menengah atas (SMA). Masyarakat belum mendapatkan pendidikan secara baik, sehingga tingkat kebutaan aksara di wilayah ini cukup tinggi. Faktor yang mempengaruhi dikarenakan pusat belajar desa yang masih kurang dan belum diperhatikan oleh pemerintah. Salah satu cara untuk meningkatkan SDM bagi masyarakat desa Mandi Angin dengan menyediakan fasilitas pendidikan bagi masyarakat secara baik dan maksimal. Tidak adanya tanggapan yang serius dari pihak pemerintah mengakibatkan menurunnya semangat belajar bagi masyarakat dan memilih pasrah dari 
ISSN : $2620-4665$ (print)

ISSN : $2620-4673$ (online)

Website : http://jurnal.untan.ac.id/index.php/JPLP2KM

harapannya. Keterbatasan dalam pendidikan akan sangat mempengaruhi kemajuan desa terutama pada bidang social dan ekonomi.

Tim PKM STKIP-PGRI Lubuklinggau akan mewujudkan harapan dari masyarakat yang memiliki semangat belajar di desa Mandi Angin. Penyediaan fasilitas berupa pembinaan yang akan diberikan kepada masyarakatnya. Tim PKM ini menyediakan Pusat Kegiatan Belajar Masyarakat (PKBM) yang akan dilaksanakan di desa tersebut sebagai bentuk dari pengabdian kepada masyarakat. Kegiatan Pusat Kegiatan Belajar Masyarakat di desa Mandi Angin telah dikonfirmasikan kepada pihak pemerintahan desa, tim melakukan observasi langsung ke lapangan dan masyarakat menyambut dengan baik. Kegiatan yang akan dilakukan oleh tim PKBM akan membantu pemerintah desa dalam mengatasi pendidikan masyarakat di desa tersebut. tujuan dari kegiatan PKBM ini adalah untuk mewujudkan harapan masyarakat yang berkeinginan untuk belajar, memberdayakan kualitas hidup dari segi pendidikan, sosial dan ekonomi. Kegiatan PKBM ini akan menyiapkan semua persiapan untuk memberikan pembinaan dalam waktu yang telah ditargetkan. Pembinaan ini akan diberikan kepada masyarakat yang memiliki kebutaan aksara yang rendah di desa Mandi Angin. sama dengan tim

PKBM (Pusat Kegiatan Belajar Masyarakat) yang dilaksanakan tim relevan dengan pengabdian itaskepada masyarakat oleh Tohani (2010) dengan judul "Strategi Pengembangan Kapasitas Pusat Kegiatan Belajar Masyarakat (PKBM) sebagai Penyedia Layanan Bidang Pendidikan". Hasil PKBM Tohari kegiatan pengembangan PKBM dalam rangka pengembangan masyarakat secara utuh pada setiap aspek kehidupan dipandang perlu untuk selalu dilakukan dalam mendukung program pemerintah di bidang pendidikan. Adanya pembinaan dari tim masyarakat desa Mandi Angin akan memiliki motivasi belajar, dan ketersediaan pusat belajar masyarakat sangat membantu pemerintah desa dalam mewujudkan harapan masyarakatnya. Berdasarkan hal di atas, permintaan pemerintah desa Mandi Angin untuk bekerja sama dengan tim PKBM (Pusat Kegiatan Belajar Masyarakat) STKIP-PGRI Lubuklinggau mengadakan pendampingan Pembentukan Struktur PKBM di desa Mandi Angin denga tema "Menggalakan PKBM menuju SDM yang bersaing Nasional".

\section{Metode Pelaksanaan}

\section{a. Peserta}

Peserta dalan kegiatan pendampingan pelaksanaan PKBM adalah masyarakat dan perangkat desa Mandi Angin kecamatan Rawas Ilir Kabupaten Musi Rawas Utara dengan jumlah yang tidak terbatas.

b. Waktu dan Tempat

Kegiatan dilaksanakan selama Sembilan hari dimulai dari tanggal 2 November 2019 sampai 28 Desember 2019. Pelaksanaan kegiatan pendampingan PKBM dilakukan di Kantor Desa dan Rumah Perangkat Desa Mandi Angin Kecamatan Rawas Ilir Kabupaten Musi Rawas Utara. 
Agar pelaksanaan kegiatan PKBM ini berjalan dengan baik, maka tim PKBM melakukan kegiatan sosialisasi dan pendampingan secara bertahap dari perangkat desa, ibu PKK dengan berbagai tingkatan masyarakat. Tahapan selama kegiatan PKBM berlangsung:

a. Identifikasi masalah, kurangnya motivasi dan pemahaman pemerintah desa Mandi Angin kecamatan Rawas Ilir kabupaten Musi Rawas Utara akan pentingnya belajar.

b. Analisis kebutuhan, Mengingat rendahnya motivasi belajar pada masyarakat desa Mandi Angin kecamatan Rawas Ilir dalam hal ini di dominasi kalangan produktif di desa Mandi Angin dalam kegiatan belajar karena kurangnya Pusat Kegiatan Belajar, maka perlu dibentuknya pusat kegiatan belajar masyarakat melalui kegiatan pendampingan pembentukan PKBM (Pusat Kegiatan Belajar Masyarakat). Kegiatan ini diharapkan kedepanya masyarakat desa Mandi Angin Kecamatan Rawas Ilir mampu menciptakan pusat kegiatan belajar masyarakat yang mandiri.

c. Penyusunan Program, Program ini dilaksanakan selama 9 hari di mulai pada tanggal 02 November - 28 Desember 2019. Pendampingan dilakukan setiap hari Sabtu, dari jam 14.00-18.00 WIB dengan sistem bergantian perklompoknya, sehingga lebih efektif. Pendampingan kegiatan PKM di awali dengan sosialisasi pada setiap komponen masyarakat, mulai dari pemerintah desa sampai dengan kalangan remaja dan anak-anak dan diakhiri dengan pembuatan struktur pengurusan PKBM (Pusat Kegiatan Belajar Masyarakat) di Desa Mandi Angin Kecamatan Rawas Ilir Kabupaten Musi Rawas Utara.

d. Program Pelaksanaan, meliputi:

1) Sosialisasi PKBM (Pusat Kegiatan Belajar Masyarakat), tahap ini pemberian materi oleh narasumber mengenai pembentukan PKBM.

2) Kegiatan pendampingan pembentukan PKBM (Pusat Kegiatan Belajar Masyarakat).

3) Struktur keanggotaan PKBM (Pusat Kegiatan Belajar Masyarakat), terdiri dari pelindung, pembimbing, ketua, wakil ketua, sekretaris, wakil sekretaris, bendahara, wakil bendahara, sesi pembelajaran, sesi sapras, sesi usaha ekonomi, sesi umum, sesi kesiswaan, sesi pendanaan, sesi pengembangan masyarakat dan masyarakat.

\section{Hasil dan Pembahasan}

\section{a. Hasil}

Luaran dalam kegiatan PKM ini adalah Jurnal PKM Nasional Cemerlang (Jurnal Pengabdian Pada Masyarakat STKIP PGRI Lubuklinggau). Selanjutnya luaran dari kegiatan PKM ini adalah terbentuknya struktur pengurusan PKBM (Pusat Kegiatan Belajar Masyarakat) di desa Mandi Angin Kecamatan Rawas Ilir Kabupaten Musi Rawas Utara.

Pelaksanaan kegiatan dilakukan selama 9 hari yang dilaksanakan mulai tanggal 02 November 2019 dan berakhir tanggal 28 Desember 2019, dengan jadwal kegiatan sebagai berikut: 
ISSN : $2620-4665$ (print)

ISSN : 2620-4673 (online)

Website : http://jurnal.untan.ac.id/index.php/JPLP2KM

\begin{tabular}{|c|c|c|c|}
\hline $\begin{array}{c}\text { Hari/ } \\
\text { Tanggal }\end{array}$ & Jam & Kegiatan & Narasumber \\
\hline \multirow{3}{*}{$\begin{array}{l}\text { Sabtu } \\
2-11- \\
2019\end{array}$} & $13.30-14.00$ & Pembukaan & Kepala Desa Mandi Angin \\
\hline & $14.00-15.00$ & $\begin{array}{l}\text { Motivasi pentingnya } \\
\text { Pendidikan }\end{array}$ & Agung Nugroho, M.Pd. \\
\hline & $16.00-17.00$ & $\begin{array}{l}\text { Sosialisasi } \\
\text { pembentukan } \\
\text { PKBM }\end{array}$ & Inda Puspita Sari, M.Pd. \\
\hline \multirow[t]{2}{*}{$\begin{array}{l}\text { Sabtu 9- } \\
11-2019\end{array}$} & $14.00-15.00$ & $\begin{array}{l}\text { Pembentukan } \\
\text { Struktur PKBM }\end{array}$ & Agung Nugroho, M.Pd. \\
\hline & $16.00-17.00$ & $\begin{array}{l}\text { Sosialisasi Peranan } \\
\text { pemeritah desa } \\
\text { dalam menunjang } \\
\text { PKBM }\end{array}$ & Inda Puspita Sari, M.Pd. \\
\hline \multirow[t]{2}{*}{$\begin{array}{l}\text { Sabtu } \\
16-11- \\
2019\end{array}$} & $14.00-15.00$ & $\begin{array}{l}\text { Pendampingan } \\
\text { penyusunan struktur } \\
\text { PKBM }\end{array}$ & Agung Nugroho, M.Pd. \\
\hline & $16.00-17.00$ & $\begin{array}{l}\text { Pendampingan } \\
\text { Penetapan Tempat } \\
\text { PKBM }\end{array}$ & Inda Puspita Sari, M.Pd. \\
\hline \multirow[t]{2}{*}{$\begin{array}{l}\text { Sabtu } \\
23-11- \\
2019\end{array}$} & $14.00-15.00$ & $\begin{array}{l}\text { Sosialisasi peranan } \\
\text { setiap komponen } \\
\text { PKBM }\end{array}$ & Agung Nugroho, M.Pd. \\
\hline & $16.00-17.00$ & $\begin{array}{l}\text { Sosialisasi peranan } \\
\text { perangkat desa pada } \\
\text { setiap komponen } \\
\text { PKBM }\end{array}$ & Inda Puspita Sari, M.Pd. \\
\hline \multirow[t]{2}{*}{$\begin{array}{l}\text { Sabtu } \\
30-11- \\
2019\end{array}$} & $14.00-15.00$ & $\begin{array}{l}\text { Sosialisasi pada } \\
\text { masyarakat Sasaran } \\
\text { PKM tentang } \\
\text { PKBM }\end{array}$ & Agung Nugroho, M.Pd. \\
\hline & $16.00-17.00$ & $\begin{array}{l}\text { Pendampingan } \\
\text { perangkat desa }\end{array}$ & Inda Puspita Sari, M.Pd. \\
\hline
\end{tabular}




\begin{tabular}{|l|l|l|l|}
\hline & & $\begin{array}{l}\text { dalam } \\
\text { mempersiapkan } \\
\text { sapras PKBM }\end{array}$ & \\
\hline \multirow{2}{*}{$\begin{array}{l}\text { Sabtu 7, } \\
14 \text { dan } \\
21-12- \\
2019\end{array}$} & $14.00-15.00$ & $\begin{array}{l}\text { Pendampingan } \\
\text { pembentukan } \\
\text { PKBM }\end{array}$ & Agung Nugroho, M.Pd. \\
\cline { 2 - 4 } & $16.00-17.00$ & $\begin{array}{l}\text { Pendampingan } \\
\text { pembentukan } \\
\text { PKBM }\end{array}$ & Inda Puspita Sari, M.Pd. \\
\hline $\begin{array}{l}\text { Sabtu } \\
28-12- \\
2019\end{array}$ & $14.00-15.00$ & $\begin{array}{l}\text { Penutupan kegiatan } \\
\text { PKBM }\end{array}$ & Kepala desa Mandi Angin \\
\hline
\end{tabular}

Pelaksanaan program pelatihan ini menggunakan metode penyuluhan atau sosialisasi, diskusi dan praktik sesuai dengan jadwal yang sudah ditentukan. Sebelumnya, tim kelompok PKM mengadakan koordinasi dengan kepala Desa dan Perangkat Desa Mandi Angin pada tanggal 20 Oktober 2019 membahas kegiatan PKM. Untuk pelaksanaan PKM pada tanggal 02 November dan 28 Desember 2019. Pada tanggal 02 November 2019 tim PKM bersama kepala desa, perangkat desa dan masyarakat membuka kegiatan PKM. Selanjutnya pada tangal 02 November 2019 di lakukan sosialisasi PKBM pada masyarakat, dari perangkat desa, kalangan anak-anak sampai orang tua.

Agar pelaksanaan kegiatan PKM ini berjalan dengan baik, maka tim PKM melakukan kegiatan sosialisasi dan pendampingan secara bertahap dari perangkat desa, ibu PKK sampai dengan berbagai tingkatan masyarakat. Setiap peserta pendampingan diberikan pelatihan secara berkala, sesuai dengan materi. Pelaksanaan kegiatan pendampingan PKBM dilakukan di Kantor Desa dan Rumah Perangkat Desa Mandi Angin Kecamatan Rawas Ilir Kabupaten Musi Rawas Utara. Karena proses pembentukan PKBM membutuhkan keterkaitan setiap komponen, maka tim PKM selalu berkoordinasi dengan pemerintah desa dan masyarakat, hal ini untuk mengefektifkan waktu

\section{b. Pembahasan}

Pelaksanaan kegiatan ini telah melalui berbagai proses dimulai dari proses:

\section{1) Indentifikasi Masalah}

Indentifikasi masalah adalah mengetahui kendala, temuan yang menjadi persoalan untuk dicari penyelesaianya hal ini sesuai dengan pendapat Sugiyono (2017:79) "Masalah merupakan area yang menjadi perhatian peneliti, suatu kondisi yang 
ISSN : $2620-4665$ (print)

ISSN : 2620-4673 (online)

Website : http://jurnal.untan.ac.id/index.php/JPLP2KM

ingin diperbaiki , atau suatu kesulitan yang ingin dieliminasi/dihilangkan”. Kurangnya motifasi dan pemahaman pemerintah dan masyarakat desa Mandi Angin kecamatan Rawas Ilir Kabupaten Musi Rawas Utara akan pentingnya belajar. Hal ini sesuai data yang penulis dapat pada saat observasi awal di desa Mandi Angin Kecamatan Rawas Ilir Kabupaten Musi Rawas Utara, sehingga ini menjadi dasar dari kegiatan PKM.

\section{2) Analisis Kebutuhan}

Mengingat rendahnya motivasi belajar pada masyarakat desa Mandi Angin kecamatan Rawas Ilir dalam hal ini di dominasi kalangan produktif di desa Mandi Angin dalam kegiatan belajar karena kurangnya Pusat Kegiatan Belajar, maka perlu dibentuknya pusat kegiatan belajar masyarakat melalui kegiatan pendampingan pembentukan PKBM (Pusat Kegiatan Belajar Masyarakat). Kegiatan ini diharapkan kedepanya masyarakat desa Mandi Angin Kecamatan Rawas Ilir mampu menciptakan pusat kegiatan belajar masyarakat yang mandiri.

\section{3) Penyusunan Program}

Program ini dilaksanakan selama 9 hari di mulai pada tanggal 02 November - 28 Desember 2019. Pendampingan dilakukan setiap hari Sabtu, dari jam 14.00-18.00 WIB dengan sistem bergantian perklompoknya, sehingga lebih efektif. Pendampingan kegiatan PKM di awali dengan sosialisasi pada setiap komponen masyarakat, mulai dari pemerintah desa sampai dengan kalangan remaja dan anak-anak dan diakhiri dengan pembuatan struktur pengurusan PKBM (Pusat Kegiatan Belajar Masyarakat) di Desa Mandi Angin Kecamatan Rawas Ilir Kabupaten Musi Rawas Utara.

\section{4) Pelaksanaan Program}

Pelaksanaan program dilaksanakan sebagai berikut:

\section{a) Sosialisasi PKBM (Pusat Kegiatan Belajar Masyarakat).}

Kegiatan pendampingan pembentukan PKBM (Pusat Kegiatan Belajar Masyarakat) lebih memfokuskan pada pembentukan struktur kepengurusan PKBM (Pusat Kegiatan Belajar Masyarakat) di desa Mandi Angin Kecamatan Rawas Ilir Kabupaten Musi Rawas. Pemberian materi oleh narasumber mengenai pembentukan PKBM (Pusat Kegiatan Belajar Masyarakat) akan mempermudah peserta untuk membuat setruktur kepengurusan PKBM (Pusat Kegiatan Belajar Masyarakat). PKBM (Pusat Kegiatan Belajar Masyarakat) adalah lembaga yang dibentuk masyarakat untuk masyarakat yang bergerak dalam bidang pendidikan, dan masih di bawah pengawasan dan bimbingan dari Dinas Pendidikan Nasional (Setia dan Lestariningsih, 2018:01). 


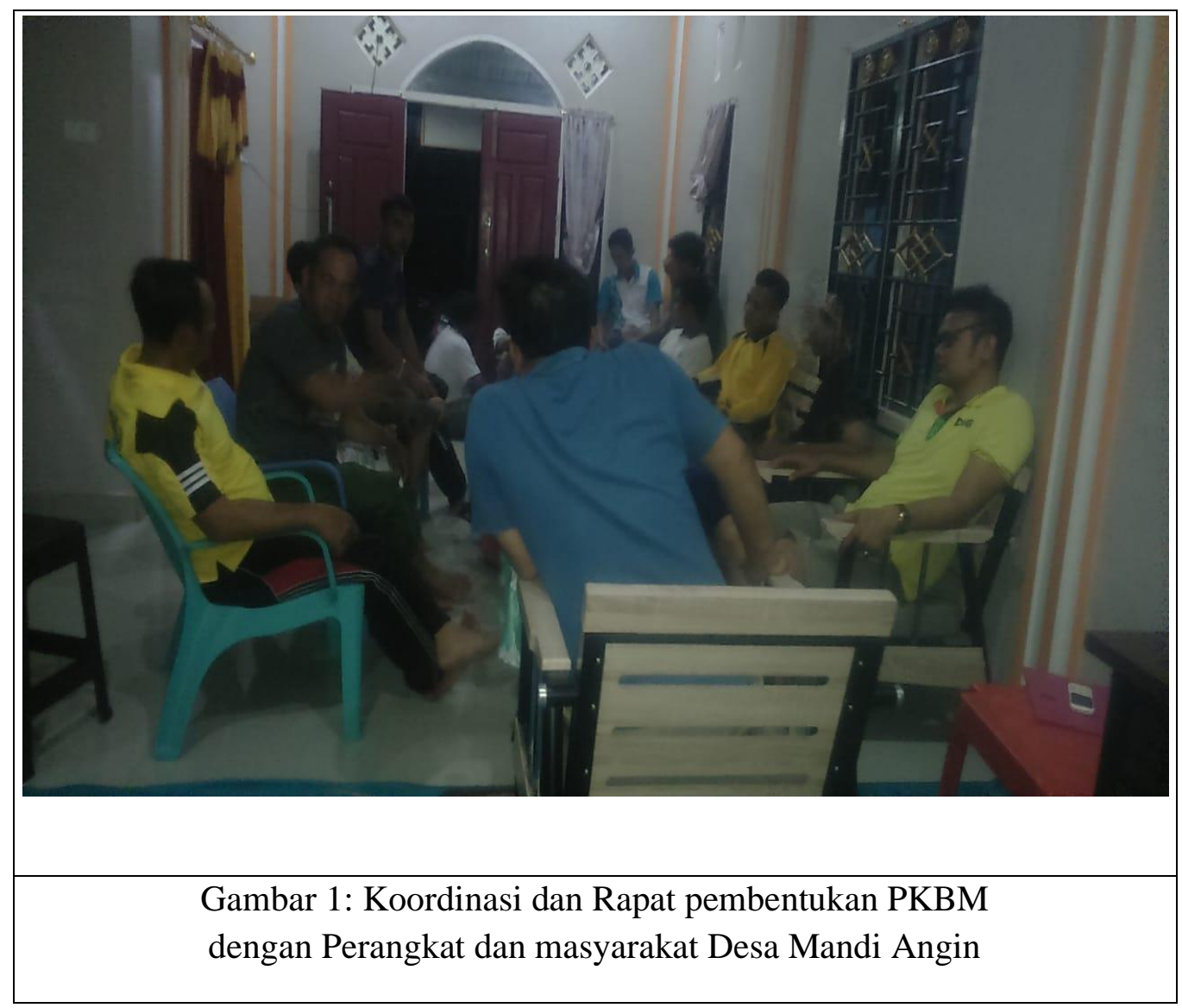

Pada kegiatan pendampingan pembentukan PKBM (Pusat Kegiatan Belajar Masyarakat) pada materi sosialisasi pembetukan PKBM disampaikan oleh Agung Nugroho, M.Pd.. Kegiatan ini hanya menekankan pada teori, sehingga peserta lebih mengenal dan memahami PKBM. Peserta terdiri perangkat desa, ibu PKK, remaja dan anak-anak di desa Mandi Angin, sehingga untuk memberikan materi metode penelitian memerlukan waktu dari jam 10.00 sampai dengan 20.00 WIB karena untuk mengefektifkan peserta pendampingan. Dalam pemberian materi narasumber dibantu oleh tim PKM yang lain dari mulai tempat sampai dengan persiapan lainya. Pemberian materi pada hari pertama peserta sangat antusias melihat betapa pentingnya PKBM bagi pendidikan masyarakat. Jumlah peserta bertambah pada pertemuan kedua dan ketiga, sehingga kegiatan PKM berjalan dengan baik. 
ISSN : $2620-4665$ (print)

ISSN : $2620-4673$ (online)

Website : http://jurnal.untan.ac.id/index.php/JPLP2KM

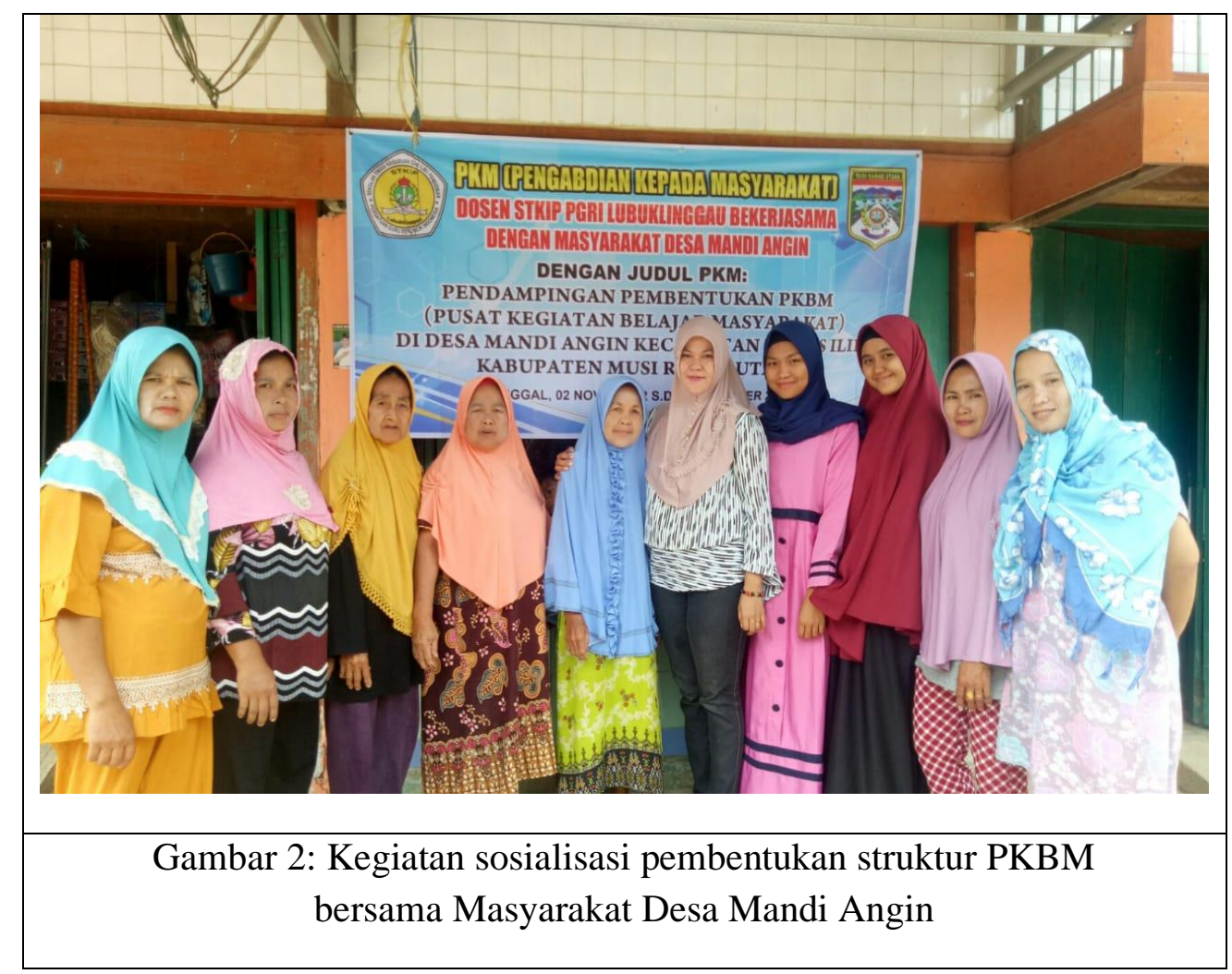

\section{b) Pembentukan Struktur PKBM (Pusat Kegiatan Belajar Masyarakat)}

Kegiatan pendampingan pembentukan PKBM (Pusat Kegiatan Belajar Masyarakat). Dilakukan pada hari sabtu, 7, 12 dan 21 Desember 2019 dengan narasumber Inda Puspita Sari, M.Pd. materi Pembentukan struktur PKBM. Adapun syarat utama pendirian PKBM antara lain: 1) Akta Notaris, 2) NPMP, 3) Susunan Badan Pengurus, 4) Seketariat dan 5) Izin Oprasional dari Dinas Pendidikan Kab/Kota (Setia dan Lestariningsih, 2018:01). Dalam hal ini tim baru sampai kepada 1) Penyusunan Badan Pengurus dan 2) Kesekertariatan, oleh sebab itu perlu dilakukan kegiatan lanjutan. Kegiatan pendampingan ini di awali dengan penentuan anggota sampai dengan anggota yang akan tercantum dalam struktur PKBM . Kegiatan pemberian materi ini peserta langsung mempraktikan proses penyusunan struktur keanggotaan PKBM. Kegiatan ini diikuti oleh perangkat desa yang sudah dipilih membutuhkan waktu 3 kali pertemuan. Peserta sangat antusias sehingga waktu yang seharusnya untuk satu kelompok 2 jam molor menjadi 3 jam. Peserta sangat antusias walau dengan kondisi tempat yang tidak memadai. 


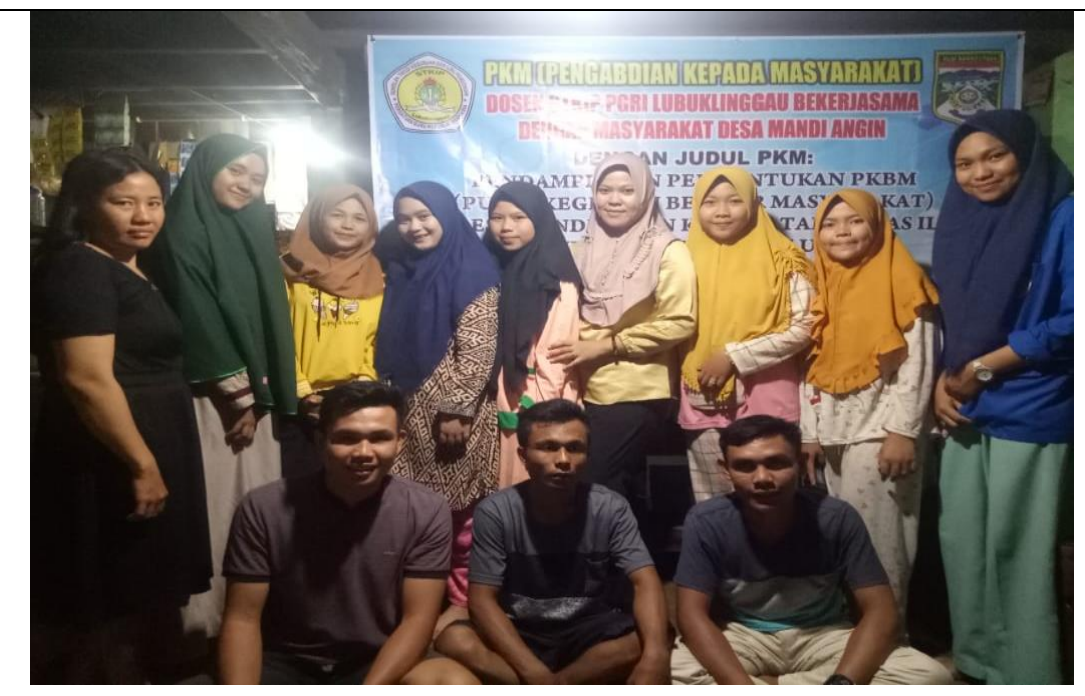

Gambar 3: Pembentukan Struktur PKBM di Desa Mandi Angin

\section{c. Struktur Keanggotaan PKBM (Pusat Kegiatan Belajar Masyarakat}

Struktur pengurusan PKBM (Pusat Kegiatan Belajar Masyarakat) di Desa Mandi Angin

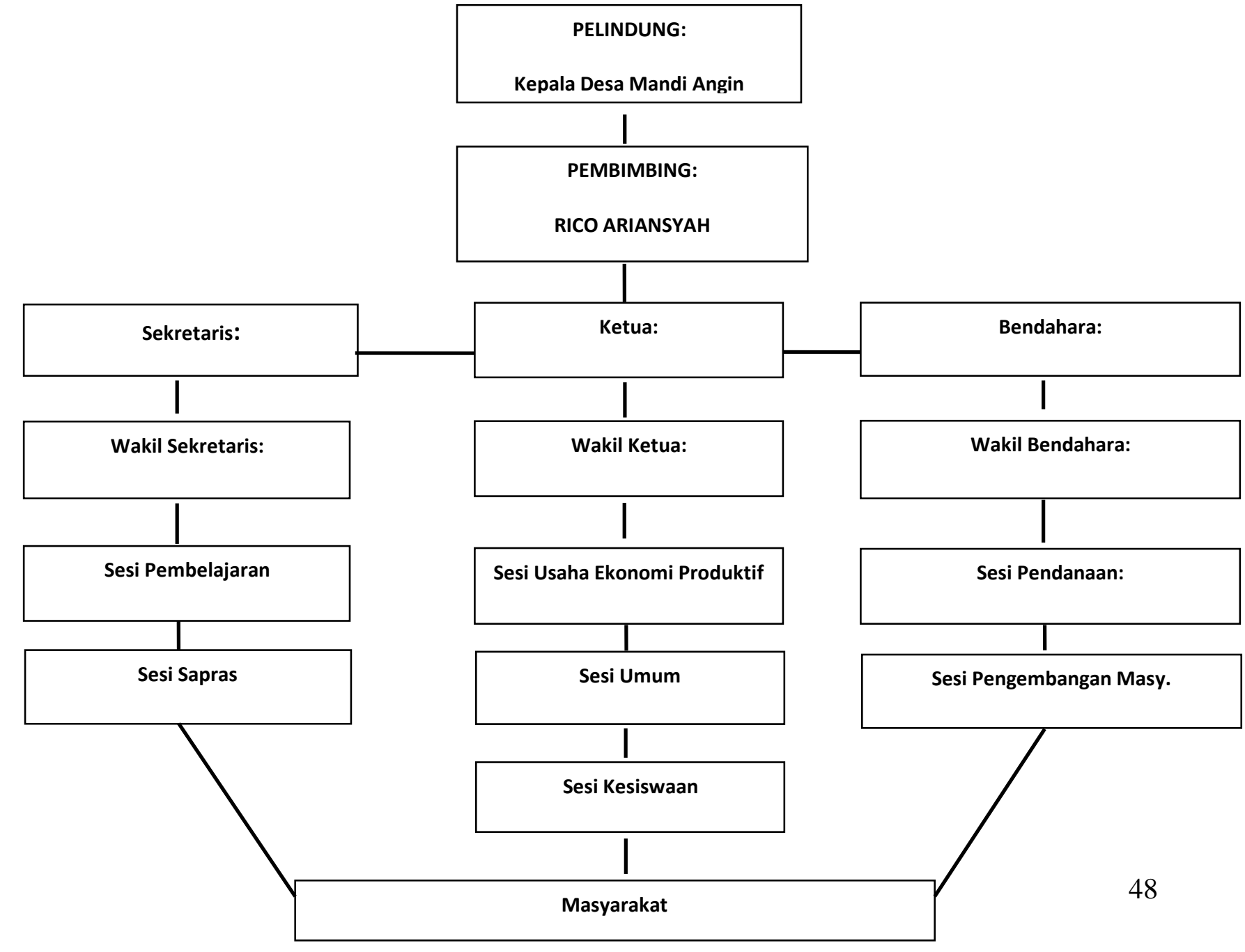


ISSN : $2620-4665$ (print)

ISSN : $2620-4673$ (online)

Website : http://jurnal.untan.ac.id/index.php/JPLP2KM

\section{Rencana Tahapan Berikutnya}

PKM ini berjudul " Pendampingan Pembentukan PKBM di Desa Mandi Angin Kecamatan Rawas Ilir Kabupaten Musi Rawas Utara". Dalam PKM ini yang menjadi subjek pelaksaan program adalah perangkat desa, ibu PKK dan remaja di desa Mandi Angin Kecamatan Rawas Ilir. Desa Mandi Angin adalah salah satu desa di kecamatan Rawas Ilir kabupaten Musi Rawas Utara. Desa Mandi Angin merupakan desa dengan jumlah penduduk 776 Kepala Keluarga dengan jumlah jiwa 2815 Orang (1396 laki-laki dan 1419 Perempuan). Masyarakat Mandi Angin mayoritas berpenghasilan sebagai petani karet dan sawit, hal ini karena sebagian besar wilayahnya terdiri dari rawa-rawa. Tingkat pendidikan di wilayah ini sangat rendah, kebanyakan masyarakat hanya menempuh pendidikan hingga jenjang Sekolah Menengah Atas (SMA). Dengan terbentuknya PKBM ini akan sedikit membantu masyarakat desa Mandi Angin dalam menciptakan pusat kegiatan belajar yang mandiri sehingga SDM dapat meningkat. Oleh karena itu tim PKM merasa tepat sasaran jika menggunakan masyarakat desa Mandi Angin tersebut sebagai subjek pelaksanaan program.

PKM ini diterima masyarakat desa Mandi Angin dengan baik oleh sebab itu tim PKM akan berusaha mengembangkankanya ketingkatan lebih tinggi tidak hanya sekedar pembentukan PKBM akan tetapi sampai dengan pembentukan Akta Notaris, NPWP dan Ijin Oprasional PKBM, sebagai bantuan dalam menyelesaikan setiap permasalahan berkaitan pendidikan di masyarakat sebagai wujud dari aplikasi ilmu yang tim PKM miliki. Selain itu tahapan berikutnya adalah pembuatan akta notaris, sehingga mampu menunjang setiap aspek yang ada dalam PKBM, sehingga akan membuka wawasan dan pengalaman baru berkaitan dengan pembentukan PKBM.

\section{Kesimpulan}

Berdasarkan uraian di atas dapat diambil kesimpulan bahwa Kegiatan pendampingan PKBM (Pusat Kegiatan Belajar Masyarakat) akan meningkatnya SDM yang mengarah pada produktifitas SDM di desa Mandi Angin. Hasil dari kegiatan PKM (Pengabdian pada Masyarakat) di desa Mandi Angin Kecamatan Rawas Ilir kabupaten Musi Rawas Utara, diantaranya: 1) Terlaksananya koordinasi tim PKM STKIP PGRI Lubuklinggau dengan pemerintah desa, sehingga kegiatan berlangsung aman dan lancar, 2) Terlaksananya sosialisasi pembentukan struktur PKBM (Pusat Kegiatan Belajar Masyarakat) dan direspon dengan baik oleh masyarakat, 3) Perangkat dan masyarakat desa Mandi Angin antusias mendukung pembentukan PKBM di desa, 4) Kendala yang dihadapi berkaitan dengan sulitnya mendapat masyarakat yang memiliki kopentensi yang tinggi, sebagai bagian dari struktur PKBM, dan 5) Pemerintah desa dan Masyarakat meminta kegiatan PKBM terlaksana dengan baik, tidak hanya sebatas pembentukan struktur kegiatanya saja. Secara umum hasil PKM ini adalah terbentuknya struktur PKBM yang akan dilanjutkan pada tingkatan pelsanaan PKBM-nya. 


\section{Daftar Pustaka}

Afsari.A.S, dkk. (2017). Peningkatan Minat Baca Para Siswa SMPN I Banjaran, Kabupaten Majalengka, Melalui Penguatan Perpustakaan Sekolah. Jurnal: Pengabdian Masyarakat UNPAD. Vol. 1 No. 2, ISSN 1410-5675. April 2017 (72-76)

Irmawati, Ais. (2017). Peran Pusat kegiatan Belajar Masyarakat (PKBM) dalam Mengurangi Buta Aksara Di Kabupaten Karimun. Jurnal: Pendidikan dan kebudayaan. Vol 2, No. 1. Juni 2017.

Octaviani.V, dkk. (2019). Peningkatan Sumber Daya Masyarakat Desa dalam Binaan Pusat Kegiatan Belajar Masyarakat (PKBM). Jurnal: Pengabdian Pada Masyarakat Universitas Mathla'ul Anwar Banten. Vol. 3, No.2, Desember 2019 (117-124).

Setia, L.D. dan Lestariningsih.T. (2018). Pelatihan Karya Tulis Bagi Guru Non Formal (PKBM Kelurahan Kertosari Ponorogo). Jurnal: Dikemas (Jurnal Pengabdian Kepada Masyarakat). Vol. 02, No. 01. Mei 2018.

Sulistyiningsih, dkk. (2013). IPTEKS Bagi Kegiatan Belajar Masyarakat (PKBM). Jurnal DEDIKASI. Vol 10, No. 1, Mei 2013 (65-67).

Sutisna, D. F. Dkk. (2012). Peranan PKBM (Pusat Kegiatan Belajar Masyarakat) dalm Menumbuhkan Minat Baca Warga Belajar. Jurnal: Mahasiswa Universitas Padjajaran. Vol. 1, no. 1.

Tohani, Entoh. (2010). Strategi Pengembangan Kapasitas Pusat Kegiatan Belajar Masyarakat (PKBM) sebagai Penyedia Layanan Bidang Pendidikan. Jurnal: Penelitian Ilmu Pendidikan. FIP UNY. Volume 03. Nomor 02. September 2010.

Wibowo, Ari, dkk. (2013). Gerakan Taman Baca "Perpustakaan Dusun" dari Mahasiswa untuk Desa. Jurnal: Inovasi dan Kewirausahaan. Vol. 2, No.1 ISSN 2089-3086 Januari 2013 (63-67). 